\title{
Political Participation of the Communities of Blitar Regency in the 2020 Simultaneous Elections
}

\author{
ABDUl HaKam SAlahUdin ${ }^{1}$, ERWIN WidHIANDONO ${ }^{2}$, DENNY ARINANDA KURNiAWAN ${ }^{3}$ \\ ${ }^{1}$ Im u Hukum, Universitas Islam Balitar, Blitar, Indonesia \\ abdulhakam@unisbablitar.ac.id \\ ${ }^{2}$ Imu Hukum, Universitas Islam Balitar, Blitar, Indonesia \\ erwinwidhiandono@unisbablitar.ac.id \\ ${ }^{3}$ Imu Sosiologi, Universitas Islam Balitar, Blitar, Indonesia \\ dennyarinanda@unisbablitar.ac.id
}

\begin{abstract}
The Covid-19 pandemic has changed patterns in all aspects of society, including its impact on political participation in society. Blitar Regency is a small example in several regions in Indonesia which carry out the 2020 simultaneous regional elections during the pandemic with a slightly different style from previous years. The purpose of the study was to determine the political participation of the Blitar district community in the 2020 simultaneous elections. The qualitative research method is a socio-political research with a normative-juridical approach with empirical data obtained from some information from informants who developed in the field. The results show that in a pandemic situation Covid-19 which has the potential to reduce public political participation in exercising their voting rights, it turns out that the Blitar Regency KPU is able to create a solution that is anticipatory, namely by implementing strict health protocols, and massive socialization either directly or digitally, so that it is able to approach the expected target, even higher from the previous two years. KPU, KPPS and the local community cooperate with each other to anticipate by trying to ensure health security during the simultaneous regional elections, also always trying to avoid possible frauds.
\end{abstract}

Keywords: political participation, blitar, pilkada, simultaneous election 


\title{
Partisipasi Politik Masyarakat Kabupaten Blitar dalam Pilkada Serentak 2020
}

\begin{abstract}
Abstrak
Pandemi Covid-19 telah merubah pola dalam segala aspek di masyarakat, termasuk dampaknya kepada partisipasi politik di masyarakat. Kabupaten Blitar menjadi contoh kecil di sebagian daerah di Indonesia yang melaksanakan Pilkada serentak 2020 di masa pandemi dengan corak yang sedikit berbeda dengan tahuntahun sebelumnya. Tujuan penelitian untuk mengetahui partisipasi politik masyarakat kabupaten Blitar dalam PILKADA serentak 2020. Metode peneltian kualitatif merupakan penelitian sosiopolitis dengan pendekatan normatif-yuridis dengan data-data empiris yang diperoleh dari beberapa informasi para informan yang berkembang di lapangan Hasil penelitian menujukkan bahwa dalam situasi pandemi Covid-19 yang berpotensi menurunkan partisipasi politik masyarakat dalam melaksanakan hak pilihnya, ternyata KPU Kabupaten Blitar mampu menciptakan antisipasi yang solutif yaitu dengan penerapan protokol kesehatan yang ketat, dan masiffnya sosialiasi baik secara langsung atau digital, sehingga mampu mendekati target yang diharapkan, bahkan lebih tinggi dari dua tahun sebelumnya. KPU, KPPS dan masyarakat setempat saling bekerjasama melaksanakan antisipasi dengan berusaha menjamin keamanan kesehatan saat pelaksanaan Pilkada serentak, juga selalu berusaha untuk menghidari kecurangan-kecurangan yang mungkin terjadi.
\end{abstract}

Kata kunci: partisipasi politik, pilkada, blitar, pilkada serentak

\section{PENDAHULUAN}

Sejak diputuskannya bahwa Indonesia juga tergolong negara yang mengalami penyebaran pandemi Covid-19 pada awal 2020 lalu, perlahan situasi dan kondisi masayarakat dan segala aspeknya mulai berubah. Dapat kita lihat, misalnya, pergeseran penggunaan media sosial yang semakin meningkat atas dasar menghindari kerumunan, telah merubah tatanan sosial dalam bidang pendidikan: dari yang awalnya tatap muka langsung menjadi serba online dan dilakukan dari jarak jauh. Sedangkan dalam hal ekonomi, imbas terburuknya memperhambat akses perdagangan sehingga melemahkan sektor-sektor produksi dan daya beli masyarakat, sehingga terjadi pemutusan hubungan kerja dimana-mana, khususnya di sektor swasta.

Pemerintah melalui Badan Pusat Statistik (BPS) 2021 juga melansir hasil survei terhadap perilaku masyarakat di masa Pandemi yang menyebutkan bahwa mayoritas responden, dalam tingkat kepatuhan terhadap protokol kesehatan, sudah cukup baik, yaitu dibuktikannya 91,98 \% mayoritas dari mereka memakai 
masker saat berada di luar rumah, dan 94,8\% responden perempuan lebih patuh dibanding dengan laki-laki (Satgas Covid 19, 2021). Meskipun demikian, pergeseran pola paling mendasar, sebagaimana telah disinggung, telah merubah tatanan sosial seperti mekanisme pemilihan daerah, yang mana dalam konteks pandemi harus dilaksanakan secara serentak, sehingga model ini berkonsekuensi pada lahirnya aturan dan kultur politik yang baru.

Regulasi Pemilihan Kepala Daerah (Pilkada) umumnya diatur dalam Undang-Undang Nomor 10 Tahun 2016 tentang Perubahan Kedua Atas UndangUndang Nomor 1 Tahun 2015 Tentang Penetapan Peraturan Pemerintah Pengganti Undang-Undang Nomor 1 Tahun 2014 Tentang Pemilihan Gubernur, Bupati, dan Walikota, dan Peraturan Komisi Pemilihan Umum (KPU): sebagai tambahan regulasi yang berbasis pada konteks protokol kesehatan saat Pandemi Covid-19 (UNISMA, 2020).

Sebelum Pandemi terjadi, semula Pilkada 2020 akan diselenggarakan pada 23 September untuk memilih 9 gubernur, 224 bupati, dan 37 walikota secara serentak di seluruh Indonesia. Namun ketika pandemi melanda, kebijakan akhirnya berubah seiring dengan terbitnya surat keputusan KPU Nomor: 179/PL.02-kpt/01/KPU/III/2020 yang berisi soal penundaan tahapan Pilkada 2020 yaitu: pelantikan dan masa kerja Panitia Pemungutan Suara (PPS), verifikasi syarat dukungan calon perseorangan, pembentukan Petugas Pemutakhiran Data Pemilih (PPDP) dan pelaksanaan pencocokan dan penelitian (coklit), serta pemutakhiran dan penyusunan daftar pemilih. Akibatnya, di sisi terberatnya yaitu perubahan jadwal dari 23 September yang semula direncanakan menjadi 9 Desember 2020 ternyata tidak berbanding lurus dengan penyebaran Pandemi Covid-19 yang semakin naik. Sementara pada sisi lain, meskipun jarak waktu tersebut akan memberi potensi positif bagi calon independen untuk melengkapi persyaratan, oleh para ahli, hal ini dinilai tetap akan bedampak pada ketidakpastian hukum karena kondisi ketidakjelasan berakhirnya pandemi (Nurhasim, 2020).

Wacana perubahan mekanisme Pilkada serentak masa pandemi, sebagaimana telah disinggung di atas, juga dapat kita lihat dari beberapa laporan dan hasil riset yang berkembang dalam ranah akademik yang ada. Nurhasim pada 2015 dan 2016 menemukan fakta bahwa Medan dan Batam memiliki problem pemutakhiran data pemilih yang sulit diperbaharui karena kedua daerah ini memiliki tingkat perantau yang tinggi. Menurutnya, jika pilkada terjadi pada masa 
pandemi maka kemungkinan kesulitan optimalisasi data pemilih yang akan dihadapi akan semakin kompleks, apalagi terbentur dengan kebijakan protokol kesehatan atau sosial distancing oleh pemerintah (Nurhasim, 2020).

Ristyawati dalam penelitiannya juga mengatakan bahwa Pilkada serentak pada Desember 2020 sebenarnya tidak realistis karena jumlah kasus positif Covid19 terus mengalami peningkatan. Namun demikian, disamping resiko penularan Covid-19 yang semakin tinggi, dan resiko kecurangan dalam pelaksanaan, sisi positifnya adalah (1) terlaksananya amanat Undang-undang, mengingat pentingnya posisi kepala daerah, (2) hak konstitusional peserta Pilkada dan hak pilih masyarakat tetap terpenuhi, (3) mengurangi praktik kepemimpinan pemerintah daerah yang terlalu banyak digantikan dengan pejabat sementara, dan (4) mencegah pembengkakan anggara. Ia menambahkan, agar Pilkada serentak 2020 ini dapat berjalan dengan baik, maka perlu penigkatan protokol kesehatan, integritas KPPS, dan sinergi dengan masyarakat (Ristyawati, 2020).

Tujuan tulisan ini adalah memperdalam kembali beberapa temuan-temuan tersebut dan mengkorelasikannya dengan apa yang terjadi di Kabupaten Blitar. Temuan data awal, daerah ini mengalami penurunan partisipasi politik masyarakat dalam Pilkada serentak 2020 masa pandemi yang oleh sebangian pengamat menjadi realitas yang menuntut solusi terbaik dalam mengatasinya. Hal ini didasarkan pada argumen bahwa Pandemi Covid-19 juga berimbas pada perubahan pola pelaksanaan Pilkada, sehingga berakibat pada menurunnya partisipasi politik masyarakat dalam menggunakan hak pilihnya. Tidak hanya itu, Pandemi Covid-19 juga berdampak pada trauma psikologis tersendiri sehingga sebagian masyarakat akan menjadi psimistis atas kinerja pemerintah dalam menangani situasi buruk ini, dan mempersepsi Pilkada menjadi jauh dari fungsi dan esensi yang sebenarnya.

\section{METODE PENELITIAN}

Penelitian ini adalah penelitian kualitatif, atau merupakan penelitian sosiopolitis dengan pendekatan normatif-yuridis dengan data-data empiris yang diperoleh dari beberapa informasi para informan yang berkembang di lapangan.Tujuannya adalah untuk mengurai perubahan perilaku partisipasi politik masyarakat Kabupaten Blitar dalam Pilkada serentak 2020, sehingga memberi informasi baru kepada masyarakat. 
Salahudin, et al. Partisipasi Politik Masyarakat Kabupaten Blitar dalam Pilkada Serentak 2020

Data primer akan diperoleh langsung dengan mempelajari beberapa beberapa informasi para informan yang berkembang di lapangan, khususnya berkaitan dengan perubahan perilaku partisipasi politik masyarakat Kabupaten Blitar dalam Pilkada serentak 2020 di masa Pandemi Covid-19. Sedangkan data sekunder diperoleh dengan memperkayanya melalui literatur-literatur yang terkait, atau dokumen tertulis lainnya yang relevan mendukung penyusunan penelitian. Hal ini diperlukan untuk memecahkan problem akademik yang telah dirumuskan sebelumnya secara terstruktur dan sistematis agar sesuai jenis penelitian yang dilakukan.

Sifat penelitian ini adalah deskriptif-analitis yang mana akan digunakan dan dipertajam dengan pendekatan yuridis-sosiologis dengan kerangka berpikir deduktif-induktif. Data-data kualitatif tentang narasi-narasi lapangan yang berkembang tentang partisipasi politik masyarakat dalam Pilkada serentak 2020 di Kabupaten Blitar pada masa pandemi Covid-19 akan dideskripsikan secara umum, kemudian menuju pada hasil analisis berdasar pada narasi aturan-aturan tentang pelaksanaan pilkada serentak 2020 yang berlaku di Indonesia.

\section{HASIL DAN PEMBAHASAN}

\section{Hasil}

Pemilu legislatif dan eksekutif yang digabungkan dalam satu hari pemilihan merupakan wacana pemilu serentak. Mark P. Jones menginterpretasi hal ini dengan menyatakan sebagai pemilu serentak jika pemilihan presiden dan anggota legislatif dilakukan pada hari yang sama dalam satu putaran, meskipun menjadi serentak penuh (simultaneous) atau sebagian (partially simultaneous).(Yusnedi, 2018, p. 65) Namun, persoalannya adalah jika pemilu model ini dterapkan pada saat pandemi yang menuntut protokol kesehatan yang ketat seperti Pembatasan Sosial Berskala Besar (PSBB) atau Pemberlakukan Pembatasan Kegiatan Masyarakat (PPKM), para ahli dengan berbagai analisisnya menilai bahwa dampak dari hal ini adalah rawannya kegiatan ketidakjujuran dalam prosesi pemilu, menurunnya partisipasi politik masyarakat, juga tingkat kesulitan para calon dalam melaksanakan kampanye (Nurhasim, 2020). Uraian-uraian deskripsi lapangan berikut menjadi bukti bahwa pelaksanaan pilkada serentak 2020 menuai polemik dan menuntut solusi terbaik dalam antisipasinya. 


\section{A. Perubahan Partisipasi Politik Pilkada Serentak 2020 di Masa Pandemi}

Indonesia merupakan bagian dari lebih dari 30 negara yang berani mengambil resiko untuk menggelar pilkada di tengah pandemi Covid-19 setelah keberhasilan Korea Selatan, Singapura dan Polandia. Padahal, data internasional menunjukkan bahwa keselamatan dan kesehatan rakyat akan menjadi resiko sekaligus ancaman. Selain itu, partisipasi politik pemilih juga akan mengalami tantangan tersendiri setelah melihat beberapa analisa di negara-negara yang akhirnya menunda pelaksanaannya seperti Hongkong dan Bolivia (Kompas, 2020).

Dalam konteks pelaksanaan Pilkada di Indonesia, Badan Pengawas Pemilu (Bawaslu) melansir data bahwa selama pengawasan kampanye secara langsung hanya terdapat 2.126 pelanggar protokol kesehatan dari jumlah seluruhnya 91.640 orang yang terlibat (Kompas, 2020). Mitigasi resiko lahirnya kluster Covid-19 Pilkada yang telah disiapkan oleh KPU merupakan cara yang diambil demi mensukseskan pelaksanaan Pilkada pada 2020, dan di sebagian daerah, khususnya di Kabupaten Blitar, tidak mengalami hal-hal yang dikhawatirkan tersebut. Artinya, tingkat partisipasi Politik dalam pelaksanaan Pilkada di Kabupaten Blitar masih relatif stabil, sebagaimana beberapa uraian dalam tulisan berikutnya.

\section{B. Partisipasi Politik Masyarakat Kabupaten Blitar}

Komisi Pemilihan Umum(KPU) Kabupaten Blitar melakukan antisipasi penurunan partisipasi politik pada pemilukada serentak 2020 dengan menerapkan mekanisme baru pemungutan suara dengan menerapkan Peraturan KPU Nomor 6 Tahun 2020 tentang Pelaksanaan Pemilihan Gubernur dan Wakil Gubernur, Bupati dan Wakil Bupati, dan/atau Walikota dan Wakil Walikota serentak lanjutan dalam kondisi Bencana non-alam Corona Virus Disease, termasuk di dalamnya mengenai penerapan mekanisme pemungutan suara yang mengutamakan protokol kesehatan.

Mekanisme yang dilakukan yaitu (1) persiapan petugas: semua petugas dipastikan melakukan telah rapid test, jika ada yang tidak memenuhi syarat maka yang bersangkutan tidak boleh mengikuti, (2) persiapan tempat: untuk mengendalikan laju Covid-19, dipilih tempat yang terbuka dan mudah dilakukan diisinfektan secara berkala. Selain itu, fasilitas sanitasi untuk pencegahan dilengkapi, dan (3) saat pelaksanaan pemungutan suara: semua yang hadir di lokasi harus menerapkan protokol kesehatan yang ketat seperti memakai masker, 
pelindung wajah, jaga jarak aman, sarung tangan sekali pakai dan pembatasan kapasitas pemilih.

“...Bagi pemilih yang sedang isolasi mandiri, atau sedang dirawat di rumah sakit, Kelompok Penyelenggara Pemungutan Suara (KPPS) setempat akan mendatangi pemilih atas persetujuan Saksi dan Panwaslu Kelurahan/Desa atau Pengawas TPS." (Endah Ayuning selaku petugas KPPS KPU Kabupaten Blitar)

Semuanya itu bertujuan untuk menghindari terjadinya electoral malpractice in election, dan sekaligus menjamin keamanan masyarakat saat datang ke TPU, mengingat rasa enggan masyarakat datang ke TPU, tetapi target partisipasi pemilih adalah 77,5 persen (BLITARKAB, 2020).

Pilkada serentak pada Desember 2020 di Kabupaten Blitar, khususnya pada Pemilihan Walikota Blitar, mengalami peningkatan melebihi target yaitu mencapai 79,2 persen. Menurut KPU Jawa Timur, artinya tingkat partisipasi masyarakat mengalami peningkatan dibanding dengan lima tahun sebelumnya, terlebih di masa pandemi seperti ini. Choirul Umam, Ketua KPU Kota Blitar, meyakini bahwa capaian ini berkat kinerja stakeholder yang melakukan sosialiasi dengan massif, pemutakhiran data yang kredibel dan penjaringan calon yang berintegritas. Berbeda dengan Pemilihan Bupati Blitar yang berada di luar ekspektasi yaitu hanya mencapai 66 persen, namun diklaim meningkat dibanding dengan dua tahun sebelumnya yaitu 55 persen. Namun demikian, dengan keadaan pandemi Covid-19 yang rawan akan turunnya tingkat partisipasi politik masyarakat, angka tersebut masih diangkap angka yang aman (Kompas, 2020).

\section{Pembahasan}

Potensi-potensi negatif dalam pelaksanan Pilkada serentak 2020 di masa pandemic Covid-19 seperti kecurangan atau terciptanya kluster baru penyebaran Covid-19 telah diantisipasi sedemikian rupa oleh KPPU di Kabupaten Blitar. Namun demikian, tentu yang akan dipertanyakan adaah soal efektifitasnya, dan sejauhmana tingkat penurunan partisipasi politik masyarakat dalam menggunakan hak pilihnya disana.

Merujuk pada temuan-temuan penelitian sebelumnya, sebagaimana kutipan Parwitasasi pada pernyataan Indra Fauzan, pengamat politik Universitas Sumatera Utara, bahwa dampak pandemi Covid-19 terhadap Pilkada serentak 2020 akan berakibat pada menurunnya partisipasi politik, karena tidak dapat dilaksanakan secara optimal, khususnya di daerah yang memiliki tingkat partisipasi politik rendah (Prawitasari \& Erowati, 2021). 
Kabupaten Blitar sendiri, dengan target partisipasi politik pemilih Pilkada serentak 2020 sebanyak 77,5 persen, telah berusaha keras untuk mewujudkan prosesnya berjalan sesuai dengan aturan yang ada, mengingat pendapat Priya Hari Santosa selaku Koordinator Divisi Pengawasan Bawaslu Kabupaten Blitar, yang menyatakan bahwa berdasarkan pada dimensi partisipasi politik, wilayahnya memiliki tingkat kerawanan yang tinggi (Blitar, 2020). Namun, pembatasan sosial yang diberlakukan oleh pemerintah secara tidak langsung juga menurunkan aktifnya partisipasi masyarakat terhadap hak pilihnya. Selain itu, di tengah ketidakpastian kapan berakhirnya pandemi, dan munculnya kebijakan pemerintah yang terkesan masih tumpang tindih membuat pola pikir masyarakat juga berubah, bahkan menjadikan optimisme mereka terhadap pasangan calon pemimpin daerah juga menurun. Oleh sebab itu, rekomendasi atas penelitian ini antara lain pemungutan suara pada masa pandemi di suatu daerah yang berpotensi menjadi kriris harus dicarikan solusi yang tepat dalam memperbaiki pola yang sudah ada.

\section{SIMPULAN}

Berdasarkan beberapa uraian hasil penelitian di atas, kesimpulan yang dapat diambil dari artikel ini bahwa pandemi Covid-19 telah berdampak pada perubahan pola masyarakat Kabupaten Blitar dalam partisipasi politik dalam Pilkada serentak 2020. Fakta menarik di Kabupaten Blitar, ternyata KPU Kabupaten Blitar mampu menciptakan antisipasi yang solutif yaitu dengan penerapan protokol kesehatan yang ketat, dan masiffnya sosialiasi baik secara langsung atau digital, sehingga mampu mendekati target yang diharapkan, bahkan lebih tinggi dari dua tahun sebelumnya. KPU, KPPS dan masyarakat setempat juga bekerjasama melaksanakan antisipasi dengan berusaha menjamin keamanan kesehatan saat pelaksanaan Pilkada serentak, juga selalu berusaha untuk menghidari kecurangan-kecurangan yang mungkin terjadi.

\section{DAFTAR PUSTAKA}

Blitar, B. (2020). skor ikp partisipasi politik tinggi ini langkah bawaslu kabupaten blitar,. Bawaslu. https://blitar.bawaslu.go.id/berita/skor-ikp-partisipasipolitik-tinggi-ini-langkah-bawaslu-kabupaten-blitar

Blitarkab, K. (2020). Cegah penurunan partisipasi pemilih kpu terapkam mekanisme baru pemungutan suara pada pemilihan serentak 2020. Kpu.Blitarkab.Go.Id. 
Salahudin, et al. Partisipasi Politik Masyarakat Kabupaten Blitar dalam Pilkada Serentak 2020

https://kpu.blitarkab.go.id/index.php/2020/12/08/cegah-penurunan-

partisipasi-pemilih-kpu-terapkan-mekanisme-baru-pemungutan-suara-pada-

pemilihan-serentak-2020

Kompas. (2020). Pandemi dan Tantangan Partisipasi Pemilih Pilkada 2020? Kompas. https://nasional.kompas.com/read/2020/12/06/12422301/pandemi-dantantangan-partisipasi-pemilih-pilkada-2020?page=all

Nurhasim, M. (2020). Dampak Pandemi COVID-19 Terhadap Pilkada 2020. Lipi. http:/ /www.politik.lipi.go.id/kolom/kolom-2/politik-nasional/ 1398-dampakpandemi-covid-19-terhadap-pilkada-2020

Prawitasari, I., \& Erowati, D. (2021). Efektivitas Pilkada Serentak Tahun 2020 di Tengah Pandemi Covid-19 Indonesia. Journal of Education, Humaniora and Social Sciences (JEHSS), 3(3), 1176-1183. https://doi.org/10.34007/jehss.v3i3.517

Ristyawati, A. (2020). Efektivitas Pelaksanaan Pilkada Serentak 2020 Pada Masa Pandemi Darurat Covid-19 Di Indonesia. Crepido, 2(2), 85-96. https://doi.org/10.14710/crepido.2.2.85-96

Satgas Covid 19. (2021). Survay Pemilih. Https://Covid19.Go.Id. https://covid19.go.id/edukasi/hasil-kajian/hasil-survei-perilaku-masyarakatdi-masa-pandemi-covid-19,

UNISMA. (2020). Kultur Pilkada Era Pandemi. Http://Pps.Unisma.Ac.Id/KulturPilkada-Era-Pandemi.

Yusnedi, Y. (2018). Analisis Dampak Pelaksanaan Pemilihan Kepala Daerah (Pilkada) Secara Serentak Terhadap Aspek Sosial Dan Ekonomi. Jurnal Manajemen Dan Bisnis. 